\title{
Sun-Moon-Earth Interactions with Larger Earthquakes Worldwide Connections
}

\author{
Marilia Hagen', Anibal Azevedo ${ }^{2}$ \\ ${ }^{1}$ Universidade Federal Fluminense, Instituto de Física, Niterói, RJ, Brasil (retired) \\ ${ }^{2}$ Faculdade de Ciências Aplicadas da Unicamp, Limeira, São Paulo \\ Email:marhagen@indiana.edu, anibal.azevedo@fca.unicamp.br
}

How to cite this paper: Hagen, M. and Azevedo, A. (2019) Sun-Moon-Earth Interactions with Larger Earthquakes Worldwide Connections. Open Journal of Earthquake Research, 8, 267-298. https://doi.org/10.4236/ojer.2019.84016

Received: September 1, 2019

Accepted: November 8, 2019

Published: November 11, 2019

Copyright $\odot 2019$ by author(s) and Scientific Research Publishing Inc. This work is licensed under the Creative Commons Attribution International License (CC BY 4.0).

http://creativecommons.org/licenses/by/4.0/ (c) (i) Open Access

\begin{abstract}
The aim of this paper is to investigate the effects on Moon-Earth gravitational variations and Moon phases during three Solar Cycless (SC22, SC23, SC24). The first part defines gravitational forces as a force that creates an oscillation when the moon is reaching the Perigee, the smallest distance between the Moon and Earth during its rotational movement around Earth. It has a small amplitude and large period. Unlikely other authors, we do not find a direct connection between the Moon phases and big earthquakes worldwide. The study is performed through the three Solar Cycless, which refers to the variation in the Sun's magnetic field. However, a strong indication appeared that almost the totality of the largest quakes studied happened preferentially at the subduction zones, in the Southern Hemisphere. In this research we apply experimental data to find the tide force, and the Perigee position is an experimental value. Other parameters are experimental, such as the length of Solar Cycless, the Moon's phases connected to each earthquake where $M \geq 7.5$. The calculations use regression in time to find the results. Our model considers in the regression the period 1986-2018.
\end{abstract}

\section{Keywords}

Solar Cycless, Moon-Earth Gravitational Forces, Larger Earthquakes

\section{Introduction}

This paper is a continuation of former research on the gravitational force variation of Moon-Earth and how it would influence the rise of worldwide earthquakes. In our former paper [1] has been verified that Moon-Earth has a gravitational force that varies during the month when the Moon is at the Perigee.

This force creates a wave with a small variation in amplitude and a large pe- 
riod, which has been calculated as well. The period analyzed was shorter than in the present study 1996-2008. The results have indicated that apparently the gravitational moon variation effects more subduction zones, and several locations which occur more earthquakes in the period studied. We also studied the possible correlation between Moon phases and earthquakes searching the historical earthquakes catalog 1700-2016. The results showed the largest earthquakes often surge at subduction zones. However, it does not have any relation with Moon phases, New Moon or Full Moon.

In the paper after that, [2] we have added the Sun to the interactions with Moon-Earth and earthquakes. The Solar Cycless comprehends a period of eleven years it was the next implicit variable used. The period analyzed for this search was 1996-2016, it included two Solar Maxima that could indicate the presence or absence of influence or not in the enhancement of quakes.

Other such studies examined the development of earthquake events during the seasons. To do this, we needed to divide the Global research into Northern and Southern Hemispheres since the seasons occur differently in each hemisphere. It was found to the Northern Hemisphere there was a slight increase in the earthquakes during Spring and Summer [3].

The present research considers three Solar Cycless, the gravitational force oscillation is calculated for each cycle, which could be a possible correspondence of large earthquakes for each maximum of the gravitational force.

Next, we ascertain a possible connection with Moon phases New or Full, which are supposed to influence the larger earthquakes that occur worldwide for each Solar Cycles, as defined under moon cycles. Larger earthquakes magnitudes depend on the region in which they are happening. During this first approach we consider the magnitudes where $M \geq 7.5$.

For these earthquakes, the following set of data includes dates, location, magnitudes, moon phases, and hemisphere, fit into each cycle, SC22, SC23, and SC24. The results show an oscillation between the moon and earth, which mainly affects the tidal waves in the subduction zones.

We will present the data set for each section studied, explaining what the explicit and implicit sets are. Our data is composed of experimental data collected from different catalogs for Solar Cycless [4], [5]; perigee/apogee data sets [6] [7], and, earthquakes [8] [9] [10]. In the case of earthquakes, it is possible to check the events in at least three worldwide catalogs.

\section{The Perigee Force Variation}

The lunar orbit around the Earth is elliptical therefore twice monthly is considered to be at the Perigee (closest to the Earth) and twice at the Apogee (the furthest from Earth). The force among the two bodies is

$$
F=G \frac{M m}{r^{2}}
$$


In Equation (1), $M$ is the Earth's mass, $\mathrm{m}$ is the moon's mass, $G=6.67 \times 10^{-11}$ $\mathrm{N} \cdot \mathrm{m}^{2} \cdot \mathrm{kg}^{-2}$ are all constants, and the only variable is $r^{2}$ which is the Earth-Moon distance. This variable is collected from the catalog [6] which also gives the value of the moon phases New Moon and Full Moon. Since the New or Full Moon sometimes are not closer to the earthquake occurrence, we also used [7].

The variation of the distance between the Earth and Moon gave a Perigee force during three Solar Cycless. The maximum $F=2.32 \times 10^{20} \mathrm{~N}$ and the minimum is $F=2.14 \times 10^{20} \mathrm{~N}$.

Several times the maximum values occurred near the Full or New Moon, but this was not a rule. The minimum values also occurring during the First or Third quarter. Therefore, there is not a real connection that the Full or New moon is attaching events at the Perigee position. The development of the force at the Perigee position shows an oscillation corroborated for each cycle searched.

We constructed Tables 1-3, for the moon cycle and the respective Solar Cycles, shown in Figures 1-3. In the figures, the maximum value corresponds to the maxima of the tidal force generated by the Equation (1).



Figure 1. SC22, the perigee variation force 1986-1996. The force is displaying a wave, with small amplitude and large period.



Figure 2. Perigee force variation during Solar Cycles 23. 




Figure 3. Perigee force variation at Solar Cycles 24.

The variations of force among Earth and Moon could possibly explain the shallow moonquake occurrences. There are four types of moonquakes [11].

Deep moonquakes have a depth of nearly $700 \mathrm{~km}$ below the surface of the moon. Meteor impacts, two-week-long thermal moonquakes, and when the darkness covers half of the moon, the temperatures can fall to -240 degrees Fahrenheit.

When that same surface makes its return to sunshine, the temperature swings wildly back to +250 degrees Fahrenheit. When the frozen crust suddenly expands, it can cause a moonquake. Shallow Moonquakes are the most powerful and the most worrisome for researchers and those eager to colonize the moon. Of the four types of quakes, these are the ones that could do some real damage.

The variation in gravitational force and oscillations created will affect the moon surface. This oscillation happens throughout the years and has a small amplitude and, large periods. The moon surface variation has different temperatures in a small period that causes cracks and fractures in its surface. This probably affects all the body since when it contracts, the temperatures fall and when it dilates it rises. It would be a cause of shallow earthquakes on the moon.

According to the references, they only happened 28 times period 1972-1977, when seismological events were observed from the instrument astronauts left behind. The magnitude of quakes observed could reach M5 [11].

\section{1) Solar Cycless, Perigee Variation, Large Earthquakes}

In order to understand our calculations, first we calculated the moon cycles and its variations by the variable $r$, into a Solar Cycles [12]. The Sun rotation magnetic field creates a giant helicoidal field that is sent through space and hit the Earth's rotational and oscillating magnetic field. Induced currents will be created parallel to this magnetic field lines according to Faraday-Maxwell equations. 
The following lists are the calculation of tide forces by each perigee position by month and year. We constructed Figures 1-3 in the text, with the data below.

Table 1. Perigee position distance, and Fg variation. Figure 1 is constructed with those values corresponding Solar Cycles 22

\begin{tabular}{|c|c|}
\hline SC 22 & \\
\hline Perigee & $\mathrm{F}_{\mathrm{g}}\left(10^{\wedge} 17 \mathrm{~N}\right)$ \\
\hline Jan. 8, 1986 & 2219 \\
\hline Feb. 4, 1986 & 2153 \\
\hline Mar. 1, 1986 & 2149 \\
\hline Mar. 28, 1986 & 2211 \\
\hline Apr. 25, 1986 & 2265 \\
\hline May 24, 1986 & 2297 \\
\hline Jun. 21, 1986 & 2289 \\
\hline Jul. 19, 1986 & 2249 \\
\hline Aug. 16, 1986 & 2190 \\
\hline Sep. 12, 1986 & 2142 \\
\hline Oct. 7, 1986 & 2172 \\
\hline Nov. 4, 1986 & 2237 \\
\hline Dec. 2, 1986 & 2289 \\
\hline Dec. 20, 1986 & 2303 \\
\hline Jan. 28, 2987 & 2274 \\
\hline Feb. 25, 1987 & 2214 \\
\hline Mar. 24, 1987 & 2151 \\
\hline Apr. 18, 1987 & 2156 \\
\hline May 15, 1987 & 2216 \\
\hline Jun.13, 1987 & 2270 \\
\hline Jul. 11, 1987 & 2298 \\
\hline Aug. 8, 1987 & 2290 \\
\hline Sep. 6, 1987 & 2249 \\
\hline Oct. 4, 1987 & 2187 \\
\hline Oct. 30, 1987 & 2139 \\
\hline Nov. 24, 1987 & 2177 \\
\hline Dec. 22, 1987 & 2245 \\
\hline Jan. 19, 1988 & 2292 \\
\hline Feb. 17, 1988 & 2292 \\
\hline Mar. 16, 1988 & 2266 \\
\hline
\end{tabular}




\section{Continued}

\begin{tabular}{|c|c|}
\hline Apr. 13, 1988 & 2207 \\
\hline May 10,1988 & 2151 \\
\hline Jun. 4, 1988 & 2157 \\
\hline Jul. 2, 1988 & 2215 \\
\hline Jul. 30, 1988 & 2268 \\
\hline Aug. 27, 1988 & 2297 \\
\hline Sep. 25,1988 & 2289 \\
\hline Oct. 23,1988 & 2246 \\
\hline Nov. 20, 1988 & 2181 \\
\hline Dec. 16, 1988 & 2135 \\
\hline Jan. 10, 1989 & 2182 \\
\hline Feb. 7, 1989 & 2249 \\
\hline Mar. 8, 1989 & 2292 \\
\hline Apr. 5, 1989 & 2296 \\
\hline May 4, 1989 & 2263 \\
\hline Jun. 1, 1989 & 2206 \\
\hline Jun. 28, 1989 & 2152 \\
\hline Jul. 23, 1989 & 2158 \\
\hline Aug. 19, 1989 & 2216 \\
\hline Sep. 16, 1989 & 2272 \\
\hline Oct. 15, 1989 & 2302 \\
\hline Nov. 12, 1989 & 2293 \\
\hline Dec. 20, 1989 & 2244 \\
\hline Jan. 7, 1990 & 2175 \\
\hline Feb. 2, 1990 & 2138 \\
\hline Feb. 28, 1990 & 2190 \\
\hline Mar. 28, 1990 & 2253 \\
\hline Apr. 25, 1990 & 2292 \\
\hline May 21, 1990 & 2294 \\
\hline Jun. 21, 1990 & 2261 \\
\hline Jul. 19, 1990 & 2205 \\
\hline Aug. 15, 1990 & 2151 \\
\hline Sep. 9, 1990 & 2159 \\
\hline Oct. 6, 1990 & 2220 \\
\hline Nov. 3, 1990 & 2278 \\
\hline Dec. 2, 1990 & 2305 \\
\hline Dec. 30, 1990 & 2289 \\
\hline Jan. 28, 1991 & 2236 \\
\hline
\end{tabular}




\section{Continued}

\begin{tabular}{|c|c|}
\hline Feb. 25, 1991 & 2168 \\
\hline Mar. 22, 1991 & 2141 \\
\hline Apr. 17, 1991 & 2194 \\
\hline May 15, 1991 & 2253 \\
\hline Jun. 13, 1991 & 2289 \\
\hline Jul. 11, 1991 & 2291 \\
\hline Aug. 8, 1991 & 2259 \\
\hline Sep. 5, 1991 & 2203 \\
\hline Oct. 2, 1991 & 2147 \\
\hline Oct. 27,1991 & 2159 \\
\hline Nov. 24, 1991 & 2224 \\
\hline Dec. 22, 1991 & 2281 \\
\hline Jan. 19, 1992 & 2304 \\
\hline Feb. 17, 1992 & 2285 \\
\hline Mar. 16, 1992 & 2230 \\
\hline Apr. 13, 1992 & 2171 \\
\hline May 8, 1992 & 2145 \\
\hline Jun. 4, 1992 & 2195 \\
\hline Jul. 2, 1992 & 2253 \\
\hline Jul. 30, 1992 & 2289 \\
\hline Aug. 27, 1992 & 2294 \\
\hline Sep. 25,1992 & 2261 \\
\hline Oct. 23,1992 & 2202 \\
\hline Nov. 19, 1992 & 2143 \\
\hline Dec. 13, 1992 & 2164 \\
\hline Jan. 10, 1993 & 2232 \\
\hline Feb. 7, 1993 & 2287 \\
\hline Mar. 8, 1993 & 2305 \\
\hline Apr. 5, 1993 & 2281 \\
\hline May 4, 1993 & 2227 \\
\hline May 31, 1993 & 2166 \\
\hline Jun. 25, 1993 & 2147 \\
\hline Jul. 22, 1993 & 2197 \\
\hline Aug. 19, 1993 & 2279 \\
\hline Sep. 16, 1993 & 2293 \\
\hline Oct. 15,1993 & 2295 \\
\hline Nov. 12, 1993 & 2259 \\
\hline Dec. 10, 1993 & 2194 \\
\hline Jan. 6, 1994 & 2138 \\
\hline
\end{tabular}




\section{Continued}

\begin{tabular}{|c|c|}
\hline Jan. 31, 1994 & 2170 \\
\hline Feb. 17, 1994 & 2237 \\
\hline Mar. 28, 1994 & 2286 \\
\hline Apr. 25, 1994 & 2301 \\
\hline May 24, 1994 & 2275 \\
\hline Jun. 21, 1994 & 2224 \\
\hline Jul. 18, 1994 & 2165 \\
\hline Aug. 12, 1994 & 2146 \\
\hline Sep. 8, 1994 & 2197 \\
\hline Oct. 6,1994 & 2257 \\
\hline Nov. 3, 1994 & 2296 \\
\hline Dec. 2, 1994 & 2295 \\
\hline Dec. 30, 1994 & 2254 \\
\hline Jan. 27, 1995 & 2188 \\
\hline Feb. 23, 1995 & 2138 \\
\hline Mar. 20, 1995 & 2175 \\
\hline Apr. 17, 1995 & 2239 \\
\hline May 15, 1995 & 2285 \\
\hline Jun. 13, 1995 & 2298 \\
\hline Jul. 11, 1995 & 2276 \\
\hline Aug. 8, 1995 & 2225 \\
\hline Sep. 5, 1995 & 2164 \\
\hline Sep. 30, 1995 & 2146 \\
\hline Oct. 26,1995 & 2201 \\
\hline Nov. 23, 1995 & 2265 \\
\hline Dec. 22, 1995 & 2301 \\
\hline Jan. 19, 1996 & 2295 \\
\hline Feb. 17, 1996 & 2249 \\
\hline Mar. 16, 1996 & 2183 \\
\hline Apr. 11, 1996 & 2141 \\
\hline May 6, 1996 & 2181 \\
\hline Jun. 3, 1996 & 2242 \\
\hline Jul. 1, 1996 & 2286 \\
\hline Jul. 30, 1996 & 2299 \\
\hline Aug. 27, 1996 & 2276 \\
\hline Sep. 24, 1996 & 2223 \\
\hline Oct. 22, 1996 & 2159 \\
\hline Nov. 16, 1996 & 2146 \\
\hline Dec. 13,1996 & 2208 \\
\hline
\end{tabular}


Table 2. Perigee position distance, and Fg variation. Figure 2 is constructed with these values. Solar Cycles 23.

\begin{tabular}{|c|c|}
\hline $\mathrm{SC} 23$ & \\
\hline Perigee & $\mathrm{F}_{\mathrm{g}} 10^{\wedge} 17 \mathrm{~N}$ \\
\hline Jan. 10, 1997 & 2270 \\
\hline Feb. 7, 1997 & 2301 \\
\hline Mar. 8, 1997 & 2289 \\
\hline Apr. 5, 1997 & 2242 \\
\hline May 5, 1997 & 2179 \\
\hline May 29, 1997 & 2142 \\
\hline Jun. 24, 1997 & 2181 \\
\hline Jul. 21, 1997 & 2241 \\
\hline Aug. 19, 1997 & 2286 \\
\hline Sep. 16, 1997 & 2299 \\
\hline Oct. 15,1997 & 2275 \\
\hline Nov. 12, 1997 & 2219 \\
\hline Dec. 9, 1997 & 2153 \\
\hline Jan. 3, 1998 & 2149 \\
\hline Jan. 30, 1998 & 2213 \\
\hline Feb. 27, 1998 & 2272 \\
\hline Mar. 28, 1998 & 2298 \\
\hline Apr. 25, 1998 & 2285 \\
\hline May 24, 1998 & 2239 \\
\hline Jun. 20, 1998 & 2179 \\
\hline Jul. 16, 1998 & 2143 \\
\hline Aug. 11, 1998 & 2181 \\
\hline Sep. 8, 1998 & 2243 \\
\hline Oct. 6, 1998 & 2290 \\
\hline Nov. 4, 1998 & 2309 \\
\hline Dec. 2, 1998 & 2275 \\
\hline Dec. 30, 1998 & 2214 \\
\hline Jan. 26, 1999 & 2148 \\
\hline Feb. 20, 1999 & 2156 \\
\hline Mar. 20, 1999 & 2219 \\
\hline Apr. 17, 1999 & 2274 \\
\hline May 15, 1999 & 2297 \\
\hline Jun. 13, 1999 & 2283 \\
\hline Jul. 11, 1999 & 2238 \\
\hline Aug. 7, 1999 & 2178 \\
\hline Sep. 2, 1999 & 2142 \\
\hline Sep. 28, 1999 & 2184 \\
\hline Oct. 26, 1999 & 2249 \\
\hline
\end{tabular}




\section{Continued}

\begin{tabular}{|c|c|}
\hline & \\
\hline Dec. 22, 1999 & 2303 \\
\hline Jan. 19, 2000 & 2268 \\
\hline Feb. 17, 2000 & 2206 \\
\hline Mar. 14, 2000 & 2145 \\
\hline Apr. 8, 2000 & 2160 \\
\hline May 6, 2000 & 2211 \\
\hline Jun. 3, 2000 & 2269 \\
\hline Jul. 1, 2000 & 2317 \\
\hline Jul. 30, 2000 & 2281 \\
\hline Aug. 27, 2000 & 2237 \\
\hline Sep. 24,2000 & 2175 \\
\hline Oct. 19,2000 & 2139 \\
\hline Nov. 14,2000 & 2186 \\
\hline Dec. 12,2000 & 2253 \\
\hline Jan. 10, 2001 & 2297 \\
\hline Feb. 7, 2001 & 2300 \\
\hline Mar. 8, 2001 & 2263 \\
\hline Apr. 5, 2001 & 2201 \\
\hline May 2, 2001 & 2147 \\
\hline May 27, 2001 & 2163 \\
\hline Jun. 23, 2001 & 2222 \\
\hline Jul. 21, 2001 & 2273 \\
\hline Aug. 19, 2001 & 2297 \\
\hline Sep. 16, 2001 & 2284 \\
\hline Oct. 14, 2001 & 2237 \\
\hline Nov. 11, 2001 & 2172 \\
\hline Dec. 6, 2001 & 2139 \\
\hline Jan. 2, 2002 & 2193 \\
\hline Jan. 30, 2002 & 2260 \\
\hline Feb. 27, 2002 & 2299 \\
\hline Mar. 28, 2002 & 2298 \\
\hline Apr. 25, 2002 & 2259 \\
\hline May 23, 2002 & 2199 \\
\hline Jun. 19, 2002 & 2147 \\
\hline Jul. 14, 2002 & 2164 \\
\hline Aug. 10, 2002 & 2224 \\
\hline Sep. 8, 2002 & 2276 \\
\hline Oct. 6,2002 & 2299 \\
\hline Nov. 4, 2002 & 2283 \\
\hline Dec. 2, 2002 & 2231 \\
\hline
\end{tabular}




\section{Continued}

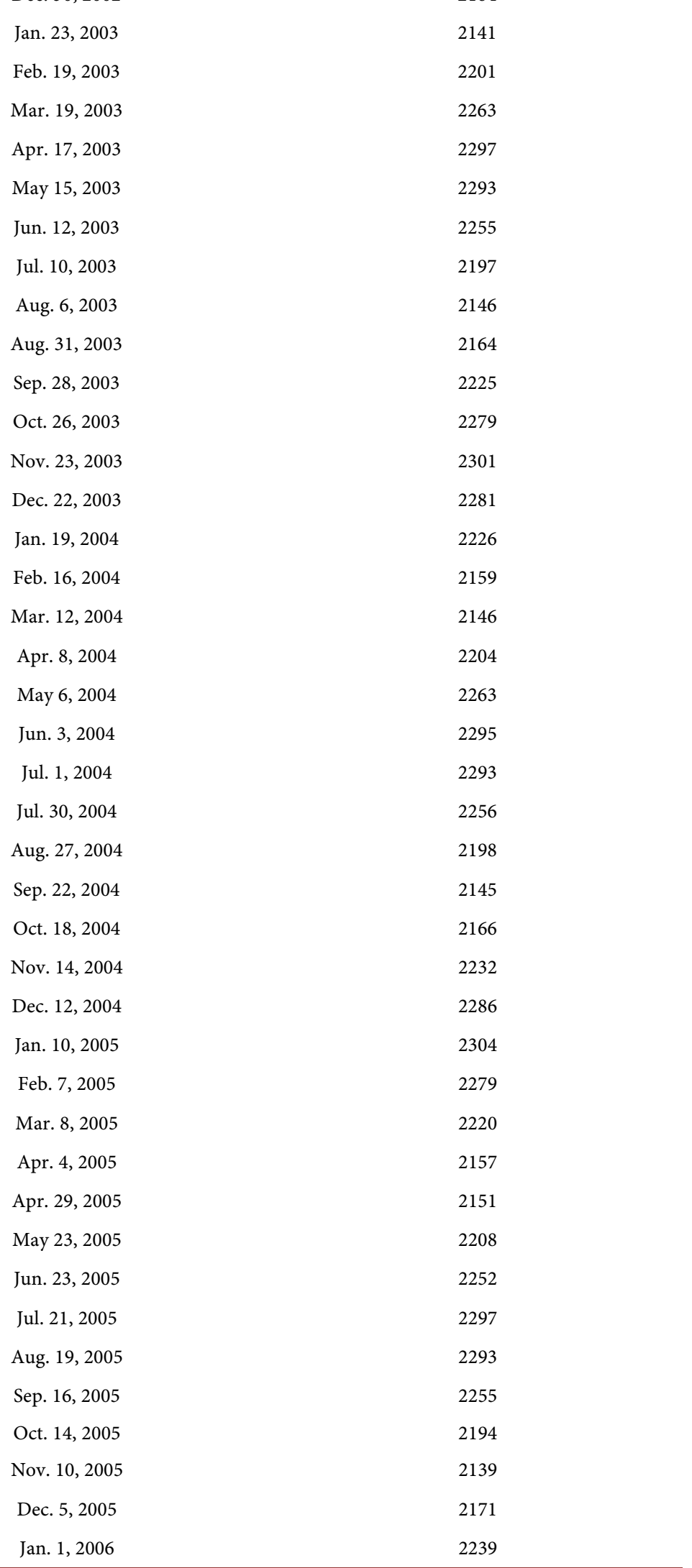




\section{Continued}

\begin{tabular}{|c|c|}
\hline Jan. 30, 2006 & 2289 \\
\hline Feb. 27, 2006 & 2300 \\
\hline Mar. 28, 2006 & 2271 \\
\hline Apr. 25, 2006 & 2214 \\
\hline May 22, 2006 & 2156 \\
\hline Jun. 16, 2006 & 2152 \\
\hline Jul. 13, 2006 & 2208 \\
\hline Aug. 10, 2006 & 2264 \\
\hline Sep. 8, 2006 & 2296 \\
\hline Oct. 6, 2006 & 2293 \\
\hline Nov. 3, 2006 & 2251 \\
\hline Dec. 2, 2006 & 2188 \\
\hline Dec. 28, 2006 & 2136 \\
\hline Jan. 22, 2007 & 2185 \\
\hline Feb. 19, 2007 & 2242 \\
\hline Mar. 19, 2007 & 2288 \\
\hline Apr. 17, 2007 & 2297 \\
\hline May 15, 2007 & 2268 \\
\hline Jun. 12, 2007 & 2214 \\
\hline Jul. 9, 2007 & 2157 \\
\hline Aug. 3, 2007 & 2153 \\
\hline Aug. 31, 2007 & 2209 \\
\hline Sep. 28, 2007 & 2268 \\
\hline Oct. 26,2007 & 2302 \\
\hline Nov. 24, 2007 & 2296 \\
\hline Dec. 22, 2007 & 2250 \\
\hline Jan. 19, 2008 & 2182 \\
\hline Feb. 14, 2008 & 2137 \\
\hline Mar. 10, 2008 & 2183 \\
\hline Apr. 7, 2008 & 2247 \\
\hline May 6, 2008 & 2289 \\
\hline Jun. 3, 2008 & 2295 \\
\hline Jul. 1, 2008 & 2267 \\
\hline July 29, 2008 & 2212 \\
\hline Aug. 26, 2008 & 2155 \\
\hline Sep. 20, 2008 & 2153 \\
\hline Oct. 17, 2008 & 2213 \\
\hline Nov. 14, 2008 & 2273 \\
\hline Dec. 1, 2008 & 2304 \\
\hline
\end{tabular}


Table 3. Perigee position distance and Fg variation. Figure 3 is constructed with these values. Solar Cycles 24.

\begin{tabular}{|c|c|}
\hline SC24 & \\
\hline Perigee day & $\mathrm{F}_{\mathrm{g}}\left(10^{\wedge} 17 \mathrm{~N}\right)$ \\
\hline Jan. 10, 2009 & 2292 \\
\hline Feb. 7, 2009 & 2242 \\
\hline Mar. 7, 2009 & 2175 \\
\hline April. 2, 2009 & 2139 \\
\hline Apr. 28, 2009 & 2186 \\
\hline May 26, 2009 & 2246 \\
\hline Jun. 23, 2009 & 2286 \\
\hline Jul. 21, 2009 & 2293 \\
\hline Aug. 19, 2009 & 2265 \\
\hline Sep. 16, 2009 & 2210 \\
\hline Oct. 13, 2009 & 2151 \\
\hline Nov. 7, 2009 & 2153 \\
\hline Dec. 4, 2009 & 2217 \\
\hline Jan. 1, 2010 & 2278 \\
\hline Jan. 30, 2010 & 2303 \\
\hline Feb. 27, 2010 & 2288 \\
\hline Mar. 28, 2010 & 2237 \\
\hline Apr. 24, 2010 & 2173 \\
\hline May 20, 2010 & 2143 \\
\hline Jun. 15, 2010 & 2188 \\
\hline July. 13, 2010 & 2246 \\
\hline Aug. 10, 2010 & 2288 \\
\hline Sep. 8, 2010 & 2296 \\
\hline Oct. 6, 2010 & 2267 \\
\hline Nov. 3, 2010 & 2209 \\
\hline Nov. 10, 2010 & 2146 \\
\hline Dec. 25, 2010 & 2158 \\
\hline Jan. 22, 2011 & 2226 \\
\hline Feb. 19, 2011 & 2283 \\
\hline Mar. 19, 2011 & 2304 \\
\hline Apr. 17, 2011 & 2285 \\
\hline May. 15, 2011 & 2234 \\
\hline Jun. 12, 2011 & 2173 \\
\hline Jul. 7, 2011 & 2145 \\
\hline Aug. 2, 2011 & 2189 \\
\hline
\end{tabular}




\section{Continued}

\begin{tabular}{|c|c|}
\hline Aug. 30, 2011 & 2249 \\
\hline Sep. 28, 2011 & 2291 \\
\hline Oct. 26, 2011 & 2298 \\
\hline Nov. 23, 2011 & 2264 \\
\hline Dec. 22, 2011 & 2201 \\
\hline Jan. 17, 2012 & 2141 \\
\hline Feb. 11, 2012 & 2164 \\
\hline Mar. 10, 2012 & 2230 \\
\hline Apr. 7, 2012 & 2281 \\
\hline May 6, 2012 & 2299 \\
\hline Jun. 3, 2012 & 2279 \\
\hline Jul. 1, 2012 & 2231 \\
\hline Jul. 29, 2012 & 2171 \\
\hline Aug. 23, 2012 & 2143 \\
\hline Sep. 19, 2012 & 2189 \\
\hline Oct. 17, 2012 & 2252 \\
\hline Nov. 14, 2012 & 2294 \\
\hline Dec. 12, 2012 & 2298 \\
\hline Jan. 10, 2013 & 2259 \\
\hline Feb. 7, 2013 & 2195 \\
\hline Mar. 5, 2013 & 2140 \\
\hline Mar. 31, 2013 & 2169 \\
\hline Apr. 27, 2013 & 2232 \\
\hline May. 27, 2013 & 2281 \\
\hline Jun. 23, 2013 & 2299 \\
\hline Jul. 21, 2013 & 2281 \\
\hline Aug. 9, 2013 & 2232 \\
\hline Sep. 15, 2013 & 2170 \\
\hline Oct. 10, 2013 & 2142 \\
\hline Nov. 6, 2013 & 2195 \\
\hline Dec. 4, 2013 & 2259 \\
\hline Jan. 1, 2014 & 2299 \\
\hline Jan. 30, 2014 & 2298 \\
\hline Feb. 27, 2014 & 2255 \\
\hline Mar. 27, 2014 & 2190 \\
\hline Apr. 23, 2014 & 2142 \\
\hline May 18, 2014 & 2173 \\
\hline
\end{tabular}




\section{Continued}

Jun. 15, 2014

2235

Jul. 13, 2014

2282

Aug. 10, 2014

2299

Sep. 8, 2014

2281

Oct. 6, 2014

2229

Nov. 3, 2014

2165

Nov. 27, 2014

2142

Dec. 24, 2014

2201

Jan. 21, 2015

2265

Feb. 19, 2015

2299

Mar. 19, 2015

2291

Apr. 17, 2015

2248

May 15, 2015

2187

Jun. 10, 2015

2143

Jul. 5, 2015

2174

Aug. 2, 2015

2234

Aug. 30, 2015

2283

Sep. 28, 2015

2301

Oct. 26, 2015

2279

Nov. 23, 2015

2225

Dec. 21, 2015

2158

Jan. 15, 2016

2144

Feb. 11, 2016

2207

Mar. 10, 2016

2267

Apr. 7, 2016

2296

May 6, 2016

2288

Jun. 3, 2016

2245

Jul. 1, 2016

2187

Jul. 27, 2016

2144

Aug. 22, 2016

2174

Sep. 18, 2016

2237

Oct. 16, 2016

2288

Nov. 14, 2016

2305

Dec. 12, 2016

2279

Jan. 10, 2017

2220

Feb. 76, 2017

2154

Mar. 3, 2017

2151

Mar. 30, 2017

2213 


\section{Continued}

\begin{tabular}{|c|c|}
\hline April 27, 2017 & 2269 \\
\hline May 26, 2017 & 2296 \\
\hline Jun. 23, 2017 & 2287 \\
\hline Jul. 21, 2017 & 2245 \\
\hline Aug. 18, 2017 & 2185 \\
\hline Sep. 13, 2017 & 2142 \\
\hline Oct. 9, 2017 & 2177 \\
\hline Nov. 6, 2017 & 2242 \\
\hline Dec. 4, 2017 & 2292 \\
\hline Jan. 1, 2018 & 2304 \\
\hline Jan. 30, 2018 & 2273 \\
\hline Feb. 27, 2018 & 2212 \\
\hline Mar. 26, 2018 & 2150 \\
\hline Apr. 20, 2018 & 2155 \\
\hline May 17, 2018 & 2214 \\
\hline Jun. 14, 2018 & 2267 \\
\hline Jul. 13, 2018 & 2293 \\
\hline Aug. 10, 2018 & 2285 \\
\hline Sep. 8, 2018 & 2244 \\
\hline Oct. 5, 2018 & 2182 \\
\hline Oct. 31, 2018 & 2138 \\
\hline Nov. 26, 2018 & 2179 \\
\hline Dec. 24, 2018 & 2247 \\
\hline
\end{tabular}

$$
\mathcal{E}=-\mathrm{d} \Phi / \mathrm{d} t
$$

In the equation $\Phi$ is the flux of the magnetic field, and $\mathcal{E}$ is the electromotive force (EMF). Therefore, Sun, rotating its axis in connection with Earth's magnetic field the Birkeland currents [13], [14], [15] and [16]. During a Solar Cycles, the Birkeland currents intensities will increase during a solar maximum for each cycle or if exceptional Coronal Mass Ejections, X flares or solar storms occur, enhancing the parallel currents and auroral lines Figure 4.

Previously we pointed out that solar storms and induced currents at the magnetosphere and ionosphere from such interaction would disturb not only the magnetosphere, but also the Earth's surface.

The Earth field is squeezed when Solar Wind speeds increase. The solar wind velocity varies in range of $300-800 \mathrm{~km} / \mathrm{s}$. Those variations affect the Earth's magnetic field with strong geomagnetic storms.

Overall, the disturbances by the Sun's magnetic field rotation creates a changing magnetic field; therefore, inducing an EMF around Earth's field lines or parallel currents. It is easier to detect this in the Earth's pole. The Earth's rotation 




Figure 4. This file is ineligible for copyright and therefore in the public domain because it consists entirely of information that is common property and contains no original authorship. The sun magnetic field lines, it varies with the solar wind speed and rotation on its axis.

also makes the dipolar magnetic field rotates. The interplanetary field is one Gauss double of the Earth's magnetic field on average. The interaction between both magnetic fields, the rotation of both bodies, and the Solar wind speed variations enhances the currents, which is known as aurora borealis.

The current intensity is enhanced by Solar wind speed variations during Coronal Mass Ejects and X flares directed toward the Earth's magnetosphere, [17].

The Solar Cycless are the Sun's magnetic field moving in a cycle. Most of the Solar Cycless are approximately eleven years, at which point the Sun's magnetic field completely flips, north and south poles exchange places. The sunspots are caused by the Sun's magnetic fields, and its varying activity during the cycles.

The beginning of a Solar Cycles is a minimum, when the Sun has the least sunspots, as we are having now in the middle of 2019. Over time, solar activity will rise, and the number of sunspots will increase. Solar Cycless have been observed since 1755 which is considered Solar Cycles 1.

Here, we are working with the following Solar Cycless; Solar Cycles 22, 1986-1996; Solar Cycles 23; 1996 (June)-2008, and Solar Cycles 24; 2008 (January)-2019 (possible end cycle). From the three pictures, we observed the Moon, when at the Perigee creates an oscillation with a period range of 52,080 hours-54,000 hours. The moon's speed around Earth is $3883 \mathrm{~km} / \mathrm{h}$ and generate a wavelength that varies between $-1.94 \times 10^{7} \mathrm{~km}-2.05 \times 10^{7} \mathrm{~km}$. It is possible to research if this wave would influence the rise of earthquakes.

The middle of the Solar Cycles is the solar maximum, or when the Sun has the most sunspots. As the cycle ends, it fades back to the solar minimum, and then a new cycle begins. In this paper, the calculations of moon forces are through of three Solar Cycless. Solar Cycless will give the interaction between the variations in the solar magnetic field and possible connections with the Moon and the Earth through earthquakes. The maximum of the first Solar Cycles analyzed (1986-1996) was July 1989. Comparing this with the data from the earthquakes, the data shows only two big earthquakes for this year; one in May 20, the other 
on Dec. 12 both during the Full moon. For the Solar Cycles 23 (1996-2008), the maximum occurred in March 2000, when the following quake events occurred May 25, May 28, June 18, November 16, November 17, all, during the Full moon. During the Solar Cycles 24 (2008-2019 September) the maximum occurred on April 2014, when five events occurred, four in April, two under the New Moon, and two during the Full Moon and one in June, under the New Moon. Therefore, the variation of the Sun magnetic field, through its cycle, showed to be stronger during the Full Moon. Examining Tables 1-3 the events occurred at the years of Maximum Solar activity and most of the New or Full moon events occurred before the earthquakes.

Here we can determine that the activity of large earthquakes will appear most at the Full moon at the maximum of Solar Cycless. Our research indicates that the Solar Magnetic Force is much more important to events on Earth than the gravitational ones between the Sun-Earth interactions. The Sun has a large and helicoidal field; the magnetic field in average on the Sun is around 1 Gauss. It is twice as strong as the average field on the surface of Earth ( 0.5 Gauss). This paragraph shows that if there is any stronger interaction between Sun-Earth it will be more in their magnetic field variation.

\section{2) Larger Earthquakes, Moon Phases}

There are four moon phases: new moon, full moon, first quarter and third quarter, and the phases in between. In this part of our research, we consider only New or Full Moon, the difference between the data and the possible connection with a large earthquake event. In the paper, [1] an extensive study was done to determine if any Moon phase was more likely to happen an earthquake $M>4.5$. At a full moon, the Earth, Moon, and Sun are in approximate alignment, just as with the New Moon, however, the moon is on the opposite side of the earth. Therefore, the entire sunlit part of the moon is facing us. To figure out if the importance of these two phases, our Tables 1-3 are constructed for each Solar Cycles; 22, 23 and 24, and the quakes searched have a magnitude $M \geq 7.5$ worldwide. Besides, the day, location and, magnitude are determined by the Moon phase on the day it happened and, also the Hemisphere. [18] The hemisphere is important for greater earthquakes since we showed in a former paper that the larger earthquakes are taking place at subduction zones which are located more at the Southern Hemisphere. The next three Tables show small differences found in the data set.

Next Table 4 defining the largest earthquakes which occurred during the SC 22.

Table 4, Solar Cycles 22 results show that quakes with magnitudes $M \geq 7.5$ more often occurred in the Southern Hemisphere (55\%), than in the Northern Hemisphere (45\%), Figure 5. Southern Hemisphere had $10 \%$ more events, located in the subduction zones. See the earthquakes above M7.8 highlighted in pink. The moon phases show that $48 \%$ occur near the Full Moon, and $52 \%$ at the New Moon, as in Figure 6. The number of total events analyzed during SC22 was the smallest from the three cycles, only 44 larger quakes occurred at total. 
Table 4. This table is showing the events of the earthquakes during period 1986-1997 (Solar Cycles 22) magnitudes $M>7.5$, the locations, and the closest Moon phase at the time (Full or New), also the Hemisphere in which it occurred.

\begin{tabular}{|c|c|c|c|c|}
\hline Data & Location & Mag & Moon phase & Hemisphere \\
\hline July 5, 1986 & Aleutian Islands & 8 & July 7, New & North \\
\hline August 14, 1986 & Molucca Sea & 7.5 & Aug. 19, Full & South \\
\hline October 20, 1986 & Kermadec Is & 7.5 & Oct. 17, Full & South \\
\hline Mar. 6, 1987 & Chile coast & 7.6 & Feb. 28, Full & South \\
\hline November 30, 1987 & Alaska & 7.8 & Nov. 30, New & North \\
\hline June 3,1988 & Alaska & 7.8 & May 27, New & North \\
\hline August 10, 1988 & Solomon Is & 7.8 & Aug. 9, Full & South \\
\hline November 6, 1988 & China & 7.7 & Nov. 9, New & North \\
\hline May 23, 1989 & Macquarie Is & 8.1 & May 20, Full & North \\
\hline Dec. 15, 1989 & Philippines & 7.6 & Dec. 12, Full & South \\
\hline Mar. 3, 1990 & Fiji Is & 7.6 & Feb. 25, New & South \\
\hline April 5, 1990 & Mariana Is & 7.6 & Mar. 26, New & North \\
\hline April 18, 1990 & Indonesia & 7.8 & Apr. 10, New & South \\
\hline July 16, 1990 & Philippines & 7.7 & July 8 , New & South \\
\hline Dec. 30, 1990 & New Britain & 7.5 & Dec. 31, Full & South \\
\hline Apr. 22, 1991 & Costa Rica & 7.6 & Apr. 14, New & North \\
\hline June 20, 1991 & Indonesia & 7.5 & Jun. 12, New & South \\
\hline Dec. 22, 1991 & Kuril Is & 7.5 & Dec. 21, Full & South \\
\hline Oct. 2, 1992 & Nicaragua & 7.7 & Sep. 26, New & North \\
\hline Dec. 12, 1992 & Indonesia & 7.8 & Dec. 9, Full & South \\
\hline January 15, 1993 & Japan & 7.5 & Jan. 8, Full & North \\
\hline June 8, 1993 & Russia & 7.5 & Jun. 4, Full & North \\
\hline July 12, 1993 & Japan & 7.7 & July 19, New & North \\
\hline August 8, 1993 & Mariana Is & 7.5 & Aug. 2, Full & North \\
\hline Mar. 9, 1994 & Fiji Is & 7.5 & Mar. 12, New & South \\
\hline Jun. 2, 1994 & Java (South) & 7.8 & May 25, Full & South \\
\hline June 9, 1994 & Bolivia (North) & 8.2 & Jun. 9, New & South \\
\hline Oct. 4, 1994 & Kuril Is & 8.2 & Oct. 5, New & North \\
\hline Dec. 28,1994 & Japan & 7.7 & Jan. 1, New & North \\
\hline May 16, 1995 & Loyalty Is & 7.7 & May 14, Full & South \\
\hline July 30, 1995 & Chile coast & 8 & Jul. 27, New & South \\
\hline Aug. 16, 1995 & Solomon Is & 7.6 & Aug. 10, Full & South \\
\hline Oct. 9, 1995 & Jalisco, Mx & 7.9 & Oct. 8, Full & North \\
\hline Dec. 3, 1995 & Kuril Is & 7.6 & Dec. 7, Full & North \\
\hline Jan. 1, 1996 & Minahasa Pen & 7.9 & Jan. 5, Full & South \\
\hline
\end{tabular}




\begin{tabular}{ccccc} 
Continued & & & \\
\hline Feb. 17, 1996 & Indonesia & 8.1 & Feb. 18, New & South \\
June 10, 1996 & Aleutian Islands & 7.6 & Jun. 16, New & North \\
June 17, 1996 & Flores sea & 7.7 & Jun. 16, New & South \\
Nov. 12, 1996 & Peru coast & 7.5 & Nov. 11, New & South \\
April 4, 1997 & Sta Cruz & 7.7 & Apr. 7, New & South \\
Nov. 8, 1997 & China & 7.5 & Nov. 14, Full & North \\
Dec. 12, 1997 & Russia & 7.8 & Dec. 14, Full & North \\
\hline
\end{tabular}



Figure 5. Solar Cycles 22, the occurrence of quakes $M \geq 7.5$, by hemisphere.



Figure 6. Solar Cycles 22, earthquakes $M \geq 7.5$ and the full or new moon occurrences.

The quasi-totality of larger events occurred at the subduction zones most frequently on the Pacific side. Pacific side is the location of most of the subduction zones if compared with Mediterranean. Rare occurrences on the Mediterranean subduction zones point out other diverse mechanisms, more than just the one discussed in this paper [18], [19].

Nevertheless, happened some exceptions to subduction zones occurred on the Myanmar-China border (1988), magnitude M7.7. Another one in Kizan (1997), M 7.5, and the last one in Northern Bolivia (1994), M8.2, at a location in a rupture point depth of $631.3 \mathrm{~km}$ below the surface. The conclusion for this Solar Cycless examining larger earthquakes indicates a possible connection between the tidal variation but not a strong bond with the Moon Phases.

There is no evidence that New or Full Moons would increase such events, at 
this point. Neither the Perigee variation enhances the frequency or magnitude of such earthquakes. Instead, the variation of the tidal wave boosts the possibility of events in such regions with a delayed time to take effect on the earthquake surge. As observed, seldom times it will happen during the perigee when the moon is closest to the Earth (two times). Southern Hemisphere occurrences are more frequent since the world presents huge rupture points in South America where the depths of earthquakes are below $600 \mathrm{~km}$ another one near the Fiji Islands (depths bigger than $700 \mathrm{~km}$ ) as it will be explained in a subsequent search.

Table 5 belongs to the Solar Cycles 23 and defining the largest earthquakes occurred into the period 1997-2008. There are 63 events in total with $M \geq 7.5$ showing similar results from Table 4 (SC22). In this table, an occurrence at the Southern Hemisphere for larger quakes happened 54\% Figure 7. From those quakes, relevant difference as New Moon had 53\% quakes, at Full 47\% tremors as shown at Figure 8. Earthquakes above or equal M7.8 are highlighted in green, Table 5.

Table 6 refers to the events to Solar Cycles 24, the last Cycle analyzed, we also highlighted the events $M \geq 7.8$ in yellow. This Cycle had a total of 66 tremors $M$ $\geq 7.5$ almost the same number of tremors as in the Cycle 23. Here the percentage of quakes that happened at the Southern is double of the Northern, see Figure 9. Figure 10 shows $57 \%$ of earthquakes happened at the New Moon.

If it is considered the period 1986-2018 the earthquakes $M \geq 7.5$ happened $59 \%$ at the Southern Hemisphere and, 55\% during the New Moon. Next, it is a study for the largest earthquakes and their occurrences by magnitude, phase and hemisphere.



Figure 7. SC23 showing the percentage of $M \geq 7.5$ earthquakes in each Hemisphere.

QUAKES M $\geq 7.5$, MOON PHASES, SC23


Figure 8. Solar Cycles 23 and the relation between quakes $M \geq 7.5$ and moon phases. 
Table 5. Belongs to the period defined as the Solar Cycles 23, and the largest earthquakes occurred at the period.

\begin{tabular}{|c|c|c|c|c|}
\hline Data & Location & Mag & Moon phases & Hemisphere \\
\hline Nov. 12, 1996 & Peru & 7.7 & Nov. 8 , New & South \\
\hline April 21, 1997 & Sta Cruz Is & 7.7 & April 20, Full & South \\
\hline Oct. 14,1997 & Fiji & 7.8 & Oct. 16, Full & North \\
\hline Nov. 8, 1997 & Xizang & 7.5 & Nov. 14, Full & North \\
\hline Dec. 5, 1997 & Kamchatka & 7.8 & Nov. 30, New & South \\
\hline Jan. 4, 1998 & Loyalty Is & 7.5 & Dec. 29,1997 , New & South \\
\hline Mar. 25, 1998 & Balleny Is & 8.1 & Mar. 13, Full & North \\
\hline May 3, 1998 & Taiwan & 7.5 & Apr. 26, New & South \\
\hline Nov. 29, 1998 & Banda Sea & 7.7 & Nov. $19, \mathrm{New}$ & North \\
\hline Aug. 17, 1999 & Turkey & 7.6 & Aug. 11, New & North \\
\hline Sep. 20, 1999 & Taiwan & 7.7 & Sep. 9, New & North \\
\hline Sep. 30, 1999 & Mexico & 7.5 & Sep. 25, Full & South \\
\hline Nov. 26, 1999 & Vanuatu & 7.5 & Nov. 23, Full & North \\
\hline Mar. 28, 2000 & Japan & 7.6 & Mar. 20, Full & South \\
\hline May 25, 2000 & Indonesia & 7.6 & May 18, Full & South \\
\hline June 18,2000 & Indian ocean & 7.9 & Jun. 16, Full & South \\
\hline Nov. 16, 2000 & Papua & 8 & Nov. 11, Full & South \\
\hline Nov. 16,2000 & Papua & 7.8 & Nov. 11, Full & South \\
\hline Nov. 17, 2000 & Papua & 7.8 & Nov. 11, Full & North \\
\hline Jan. 1, 2001 & Phil & 7.5 & Dec. $25,2000, \mathrm{New}$ & North \\
\hline Jan. 13, 2001 & El Salvador & 7.7 & Jan. 9, Full & North \\
\hline Jan. 26, 2001 & India & 7.7 & Jan. 24, New & north \\
\hline June 23, 2001 & Peru & 8.4 & June 21, New & South \\
\hline July 7, 2001 & Peru & 7.6 & July 5, Full & South \\
\hline Oct. 19, 2001 & Banda Sea & 7.5 & Oct. 1, New & South \\
\hline Nov. 14, 2001 & China & 7.8 & Nov. 1, Full & North \\
\hline Mar. 5, 2002 & Phil & 7.5 & Feb. 27, Full & North \\
\hline 19 Aug., 2002 & Fiji & 7.7 & Aug. 8, New & South \\
\hline 19 Aug., 2002 & Fiji & 7.7 & Aug. 8, New & South \\
\hline 8 Sep., 2002 & N Guinea & 7.6 & Sep. 7, New & North \\
\hline 10 Oct., 2002 & Indonesia & 7.6 & Oct. 6, New & South \\
\hline 3 Nov., 2002 & Alaska & 7.9 & Nov. 4 , New & North \\
\hline 22 Jan., 2003 & Mexico & 7.6 & Jan. 18, Full & North \\
\hline 15 July, 2003 & Carls. Ridge & 7.6 & July 13, Full & North \\
\hline 4 Aug., 2003 & Scotia Sea & 7.6 & July 29, Full & South \\
\hline 25 Sep., 2003 & Japan & 8.2 & Sep. 26, New & North \\
\hline
\end{tabular}




\section{Continued}

\begin{tabular}{|c|c|c|c|c|}
\hline 17 Nov., 2003 & Alaska & 7.8 & Nov. 9, Full & North \\
\hline 11 Nov., 2004 & Indonesia & 7.5 & Nov. 12, New & South \\
\hline 23 Dec., 2004 & Macq. Is & 8.1 & Dec. 26, Full & South \\
\hline 26 Dec., 2004 & Sumatra & 9.1 & Dec. 26, Full & North \\
\hline 28 Mar., 2005 & Indonesia & 8.6 & Mar. 25, Full & North \\
\hline 13 June, 2005 & Chile & 7.8 & June 6, New & South \\
\hline 9 Sep., 2005 & Papua & 7.6 & Sep. 3, New & South \\
\hline 26 Sep., 2005 & Peru & 7.5 & Sep. 18, Full & South \\
\hline 8 Oct., 2005 & Pakistan & 7.6 & Oct. 3 , New & North \\
\hline 27 Jan., 2005 & Banda Sea & 7.6 & Jan. 29, New & South \\
\hline 20 Apr., 2006 & Russia & 7.6 & Apr. 13, Full & North \\
\hline 3 May, 2006 & Tonga & 8 & Apr. 27, New & South \\
\hline 17 July, 2006 & Java & 7.7 & Jul. 11, Full & South \\
\hline 15 Nov., 2006 & Kuril Is & 8.3 & Nov. 20, New & North \\
\hline 13 Jan., 2007 & Kuril Is & 8.1 & Jan. 19, New & North \\
\hline 21 Jan., 2007 & Molucca Sea & 7.5 & Jan. 19, New & South \\
\hline 1 Apr., 2007 & Solomon Is & 8.1 & Apr. 2, Full & South \\
\hline 8 Aug., 2007 & Indonesia & 7.5 & Jul. 30, Full & South \\
\hline 15 Aug., 2007 & Peru & 8 & Aug. 12, New & South \\
\hline 12 Sep., 2007 & Indonesia & 8.4 & Sep. 11, New & South \\
\hline 12 Sep., 2007 & Indonesia & 7.9 & Sep. 11, New & South \\
\hline 28 Sep., 2007 & Japan & 7.5 & Sep. 26, Full & North \\
\hline 14 Nov., 2007 & Chile & 7.7 & Nov. 9, New & South \\
\hline 9 Dec., 2007 & Fiji & 7.8 & Dec. 9, New & South \\
\hline 12 May, 2008 & China & 7.9 & May 5, New & North \\
\hline 5 July, 2008 & Okhotsk Sea & 7.7 & Jul. 3, New & North \\
\hline
\end{tabular}

Table 6. Larger earthquakes $(M \geq 7.5)$ during the Solar Cycles 24, data, location, moon phase (new/full) and hemisphere. The data highlighted are $M \geq 7.8$.

\begin{tabular}{ccccc}
\hline Data & Location & Mag & Moon phase & Hemisphere \\
\hline Jan. 3, 2009 & Indonesia & 7.7 & Dec. 27 (08), New & South \\
Mar. 19, 2009 & Tonga & 7.6 & Mar. 11, Full & South \\
July 15, 2009 & New Zealand & 7.8 & Jul. 7, Full & South \\
August 10, 2009 & India & 7.5 & Aug. 6, Full & North \\
Sep. 29, 2009 & Samoa Is & 8.1 & Sep. 18, New & South \\
Sep. 30, 2009 & Indonesia & 7.6 & Sep. 18, New & South \\
Oct. 9, 2009 & Vanuatu & 7.7 & Oct. 4, Full & South \\
Oct. 7, 2009 & Sta Cruz Is & 7.8 & Oct. 4, Full & South \\
\hline
\end{tabular}




\section{Continued}

\begin{tabular}{|c|c|c|c|c|}
\hline Feb. 27, 2010 & Chile & 8.8 & Feb. 28, Full & South \\
\hline Apr. 6, 2010 & Indonesia & 7.8 & Mar. 30, Full & South \\
\hline Jun. 12, 2010 & India & 7.5 & Jun. 12, New & North \\
\hline Jul. 23, 2010 & Philippines & 7.6 & Jul. 26, Full & South \\
\hline July 23, 2010 & Philippines & 7.5 & Jul. 26, Full & South \\
\hline Oct. 25,2010 & Indonesia & 7.8 & Oct. 23, Full & South \\
\hline Mar. 3, 2011 & Japan & 9.1 & Mar. 4, New & North \\
\hline Mar. 11, 2011 & Japan & 7.9 & Mar. 4, New & North \\
\hline Mar. 11, 2011 & Japan & 7.7 & Mar. 4, New & North \\
\hline July 6, 2011 & Kermadec Is & 7.6 & Jul. 1, New & South \\
\hline Apr. 11, 2012 & Sumatra & 8.6 & April 6, Full & South \\
\hline April 11, 2012 & Sumatra & 8.2 & April 6, Full & South \\
\hline Aug. 14, 2012 & Sea of Okhotsk & 7.7 & Aug. 17, New & North \\
\hline Aug. 31, 2012 & Philippines & 7.6 & Aug. 31, New & North \\
\hline Sep. 5, 2012 & Costa Rica & 7.6 & Aug. 31, New & North \\
\hline Oct. 28, 2012 & Canada & 7.8 & Oct. $20, \mathrm{New}$ & North \\
\hline Jan. 5, 2013 & Alaska & 7.5 & Dec. 28, Full & North \\
\hline Feb. 6, 2013 & Solomon Is & 8 & Feb. 10, New & South \\
\hline Apr. 16, 2013 & Iran & 7.7 & Apr. 10, New & North \\
\hline May 24, 2013 & Sea of Okhotsk & 8.3 & May 25, Full & North \\
\hline Sep. 24, 2013 & Pakistan & 7.7 & Sep. 19, Full & North \\
\hline Nov. 13, 2013 & Scotia Sea & 7.7 & Nov. 17, Full & South \\
\hline Apr. 1, 2014 & Chile & 8.2 & Mar. 30, New & South \\
\hline Apr. 3, 2014 & Chile & 7.7 & Mar. 30, New & South \\
\hline Apr. 12, 2014 & Solomon Is & 7.6 & Apr. 15, Full & South \\
\hline Apr 19, 2014 & Papua & 7.5 & Apr. 15, Full & South \\
\hline Jun. 23, 2014 & Alaska & 7.9 & Jun. 27, New & North \\
\hline Mar. 29, 2015 & Papua & 7.5 & Mar. 20, New & South \\
\hline Apr. 25, 2015 & Nepal & 7.8 & Apr. 18, New & North \\
\hline May 5, 2015 & Papua & 7.5 & May 4, Full & South \\
\hline May 30,2015 & Japan & 7.8 & Jun. 2, Full & North \\
\hline Sep. 16, 2015 & Chile & 8.3 & Sep. 13, New & South \\
\hline Oct. 26,2015 & Afghanistan & 7.5 & Oct. 27, Full & North \\
\hline Nov. 24, 2015 & Peru & 7.6 & Nov. 25, Full & South \\
\hline Nov. 24,2015 & Brazil & 7.6 & Nov. 25, full & South \\
\hline Mar. 2, 2016 & Indonesia & 7.8 & Mar. 9, New & South \\
\hline Apr. 16, 2016 & Ecuador & 7.8 & Apr. 7, New & South \\
\hline July 29, 2016 & Mariana IS & 7.7 & Jul. 19, Full & North \\
\hline
\end{tabular}




\begin{tabular}{ccccl} 
Continued & \multicolumn{3}{l}{} & \\
\hline Nov. 13, 2016 & N. Zealand & 7.8 & Nov. 14, Full & South \\
Dec. 8, 2016 & Solomon Is & 7.8 & Nov. 29, New & South \\
Dec. 17, 2016 & Papua & 7.9 & Dec. 14, New & South \\
Dec. 25, 2016 & Chile & 7.6 & Dec. 29, New & South \\
Jan. 22, 2017 & Papua & 7.9 & Jan. 11, New & South \\
Jul. 17, 2017 & Russia & 7.7 & Jul. 9, New & North \\
Sep. 8, 2017 & Mexico & 8.2 & Sep. 6, New & North \\
Jan. 10, 2018 & Honduras & 7.5 & Jan. 2, Full & North \\
Jan. 23, 2018 & Alaska & 7.9 & Jan. 17, New & North \\
Feb. 22, 2019 & Papua & 7.5 & Feb. 15, New & South \\
Aug. 19, 2018 & Fiji & 8.2 & Aug. 11, New & South \\
Sep. 6, 2018 & Fiji & 7.9 & Sep. 9, New & South \\
Sep. 28, 2018 & Indonesia & 7.5 & Sep. 25, Full & South \\
Dec. 5, 2018 & N. Caledonia & 7.5 & Dec. 7, New & South \\
Feb. 22, 2019 & Ecuador & 7.5 & Feb. 19, New & South \\
May 14, 2019 & Papua & 7.6 & May 18, New & South \\
May 26, 2019 & Peru & 7.5 & May 18, New & South \\
\hline
\end{tabular}



Figure 9. Solar Cycles 24 showing the relation North/south hemisphere for earthquakes $M \geq 7.5$.

SC24, EARTHQUAKES $M \geq 7.5$, MOON PHASES



Figure 10. It is the percentage of events that occurred at the full or new moon. Earthquakes $M \geq 7.5$, during the Solar Cycles 24 . 


\section{Solar Cycles 22, Solar Cycles 23, Solar Cycles 24, Comparisons with Data}

The data set for three Solar Cycless, make it possible to find out how much the gravitational force of Moon-Earth variation and the tectonics influence on subduction zones can increase the number of events during these periods. Initially we considered larger events the earthquakes $M \geq 7.5$ separating by cycles.

Comparing the events found the Solar Cycles 22 has the smallest number of larger events. During Solar Cycles 22, 44 larger events, Solar Cycles 23, 63 larger events, and Solar Cycles 24, 66 larger events occurred. Solar Cycles 24, presenting double the number of tremors at the Southern Hemisphere than the other two cycles. Also, the quakes happened with more frequency at or close to the New Moon. Therefore, there is the Solar Cycless maximum, Moon Phases (New or Full), and the correlated variation on the tidal forces as we did at the first part of this paper. All these variables appear to be correlated to the of subduction zones locations. Full moon looks to be important during the Solar Cycles maximum, when the biggest events occurred at the subduction zones and tightly correlated with this phase.

\section{Largest ( $M \geq 7.8)$ Earthquakes vs. Moon Phases, Hemispheres}

The latest results from Section 3 showed that earthquakes tend to appear in the Southern Hemisphere during the new moon. The goal now is to study what happens to the highest magnitude earthquakes that occurred in the last three cycles over a period between 1986-2018. We extracted the highlighted data from the last three Tables 4-6 and constructed three new ones.

Tables 7-9 are earthquakes with magnitude $M \geq 7.8$ for each cycle studied. The tables show the date they occurred, the locations, hemisphere magnitude, with a difference as the exact moon phase nearest the occurred earthquake.

Table 7 displays the largest earthquakes $M \geq 7.8$ during the Solar Cycles 22 . The column for the Moon phases, showing the closest phase to the event, two events occurred at the 1 st $\mathrm{Q}$, five at the New moon, two at the 3rd Q and four at the full Moon. Therefore, the New moon is still the phase when more events happened for this Cycle.

Table 8, the relation between the Moon phases and the earthquakes are the following, four at the 1 st Q, five at the $3 \mathrm{rd} \mathrm{Q}$, five at the Full moon, and nine at the New moon. On this cycle the New moon has a higher occurrence than the other three phases, SC23.

Table 9 is the last cycle studied or SC24 displaying the major events with the same parameters analyzed for the other two cycles. In this cycle the moon phases are six for New and 3rdQ, and eight for Full and 1st Q.

Analyzing the moon phases for the entire period 1986-2018 the totality of earthquakes happened according to the moon phases 1st and 3rd Q had 14 and 13 largest events respectively, full moon, 17 events, and New moon 20 events it means that largest events happened most at the New Moon, $31 \%$ followed by the Full Moon 27\%. 
Table 7. Showing the parameters for the largest earthquakes on the cycle SC2, M $\geq 7.8$.

\begin{tabular}{ccccc}
\hline Data & Location & Mag & Moon phase & Hemisphere \\
\hline Nov. 30, 1987 & Alaska & 7.8 & Nov. 28, 1st Q & North \\
Aug 10, 1988 & Solomon Is & 7.8 & Aug. 12, New & South \\
May 23, 1989 & Macquarie Is & 8.1 & May 20, Full & North \\
April 18, 1990 & Indonesia & 7.8 & Apr. 18, 3rd & South \\
Dec. 12, 1992 & Indonesia & 7.8 & Dec. 9, Full & South \\
Jun. 2, 1994 & Java (South) & 7.8 & Jun. 1, 3rd & South \\
June 9, 1994 & Bolivia-North & 8.2 & Jun. 9, New & South \\
Oct. 4, 1994 & Kuril Is & 8.2 & Oct. 5, New & North \\
July 30, 1995 & Chile coast & 8 & Jul. 27, New & South \\
Oct. 9, 1995 & Jalisco, Mx & 7.9 & Oct. 8, Full & North \\
Jan. 1, 1996 & Minahasa Pen & 7.9 & Dec. 28, 1st Q & South \\
Feb. 17, 1996 & Indonesia & 8.1 & Feb. 18, New & South \\
Dec. 12, 1997 & Russia & 7.8 & Dec. 14, Full & North \\
\hline
\end{tabular}

Table 8. Showing the major events $M \geq 7.8$ occurred worldwide for the SC23. Here the major events at the Northern Hemisphere happen during the minimum of the cycle, or 2003-2007.

\begin{tabular}{ccccc}
\hline Data & Location & Mag & Moon phases & Hemisphere \\
\hline Dec. 5, 1997 & Kamchatka & 7.8 & Dec. 7, 1st Q & South \\
Mar. 25, 1998 & Balleny Is & 8.1 & Mar. 28, New & North \\
June 18, 2000 & Indian ocean & 7.9 & Jun. 16, Full & South \\
Nov. 16, 2000 & Papua & 8 & Nov. 18, 3rd Q & South \\
Nov. 16, 2000 & Papua & 7.8 & Nov. 18, 3rd Q & South \\
Nov. 17, 2000 & Papua & 7.8 & Nov. 18, 3rd Q & North \\
June 23, 2001 & Peru & 8.4 & June 21, New & South \\
Nov. 14, 2001 & China & 7.8 & Nov. 15, New & North \\
3 Nov., 2002 & Alaska & 7.9 & Nov. 4, New & North \\
25 Sep., 2003 & Japan & 8.2 & Sep. 21, Full & North \\
17 Nov., 2003 & Alaska & 7.8 & Nov. 20, Full & North \\
23 Dec., 2004 & Macq. Is & 8.1 & Dec. 23, New & South \\
26 Dec., 2004 & Sumatra & 9.1 & Dec. 23, New & North \\
28 Mar., 2005 & Indonesia & 8.6 & Mar. 25, Full & North \\
13 June, 2005 & Chile & 7.8 & June 15, 1st Q & South \\
3 May, 2006 & Tonga & 8 & May 5, 1st Q & South \\
15 Nov., 2006 & Kuril Is & 8.3 & Nov. 17, 3rd Q & North \\
13 Jan., 2007 & Kuril Is & 8.1 & Jan. 11, 3rd Q & North \\
\hline
\end{tabular}


Continued

\begin{tabular}{ccccc}
\hline 1 Apr., 2007 & Solomon Is & 8.1 & Apr. 12, Full & South \\
15 Aug., 2007 & Peru & 8 & Aug. 12, New & South \\
12 Sep., 2007 & Indonesia & 8.4 & Sep. 11, New & South \\
12 Sep., 2007 & Indonesia & 7.9 & Sep. 11, New & South \\
12 May, 2008 & China & 7.9 & May 12, 1st Q & North \\
\hline
\end{tabular}

Table 9. Displaying the data for earthquakes $M \geq 7.8$ during the SC24.

\begin{tabular}{|c|c|c|c|c|}
\hline Data & Location & Mag & Moon phase & Hemisphere \\
\hline July 15, 2009 & New Zealand & 7.8 & Jul. 15, 1st Q & South \\
\hline Sep. 29, 2009 & Samoa Is & 8.1 & Sep. 26, 1st Q & South \\
\hline Oct. 7, 2009 & StaCruz Is & 7.8 & Oct. 4, Full & South \\
\hline Feb. 27, 2010 & Chile & 8.8 & Feb. 28, Full & South \\
\hline Apr 6, 2010 & Indonesia & 7.8 & Apr. 6, 3rd Q & South \\
\hline Oct. 25,2010 & Indonesia & 7.8 & Oct. 23, Full & South \\
\hline Mar. 3, 2011 & Japan & 9.1 & Mar. 4, New & North \\
\hline Mar. 11, 2011 & Japan & 7.9 & Mar. 12, 1st Q & North \\
\hline Apr. 11, 2012 & Sumatra & 8.6 & Apr. 13, 3rd Q & South \\
\hline April 11, 2012 & Sumatra & 8.2 & Apr. 13, 3rd Q & South \\
\hline Oct. 28,2012 & Canada & 7.8 & Oct. 29, Full & North \\
\hline Feb. 6, 2013 & Solomon Is & 8 & Feb. 3, 3rd Q & South \\
\hline May 24, 2013 & Sea of Okhotsk & 8.3 & May 25, Full & North \\
\hline Apr. 1, 2014 & Chile & 8.2 & Mar. 30, New & South \\
\hline Jun. 23, 2014 & Alaska & 7.9 & Jun. 27, New & North \\
\hline Apr. 25, 2015 & Nepal & 7.8 & Apr. 25, 1st Q & North \\
\hline May 30, 2015 & Japan & 7.8 & Jun. 2, Full & North \\
\hline Sep. 16, 2015 & Chile & 8.3 & Sep. 13, New & South \\
\hline Mar. 2, 2016 & Indonesia & 7.8 & Mar. 1, 3rd Q & South \\
\hline Apr. 16, 2016 & Ecuador & 7.8 & Apr. 14, 1st Q & South \\
\hline Nov. 13, 2016 & N. Zealand & 7.8 & Nov. 14, Full & South \\
\hline Dec. 8, 2016 & Solomon Is & 7.8 & Dec. 7, 1st Q & South \\
\hline Dec. 17, 2016 & Papua & 7.9 & Dec. 14, Full & South \\
\hline Jan. 22, 2017 & Papua & 7.9 & Jan. 19, 3rd Q & South \\
\hline Sep. 6, Full & Mexico & 8.2 & Sep. 6, New & North \\
\hline Jan. 23, 2018 & Alaska & 7.9 & Jan. 24, 1st Q & North \\
\hline Aug. 19, 2018 & Fiji & 8.2 & Aug. 18, 1st Q & South \\
\hline Sep. 6, 2018 & Fiji & 7.9 & Sep. 9, New & South \\
\hline
\end{tabular}


Tables 6-8, for SC22, SC23 and SC24 results, resumed in Figure 11. Figure 11 represents the three tables, (Tables 7-9) for the biggest earthquakes worldwide $\mathrm{M}>$ or equal 7.8. Observe Tables 7-9 are the biggest earthquakes worldwide for each cycle we searched. Analyzing the three cycles by Hemisphere and Moon Phases, for the largest earthquakes, the results are the following; the biggest occurrences are in the Northern Hemisphere for SC22 (57\%), to SC23 was at the Southern Hemisphere (53\%) and for SC24 at the Southern Hemisphere (65\%). It pointed out the earthquakes likely to happen more at the Southern hemisphere with a small discrepancy on the SC22. The same analysis for the Moon phase for the largest events showing a growth of events in conjunction with a New Moon. The New Moon appears in 57\% (SC22), 59\% in (SC23) and 78\% (SC24\%). Considering the entire period 1986-2018, for earthquakes $\mathrm{M} \geq 7.8$ we obtained to the Moon phases is 31\% for New Moon and 27\% for Full moon. The Southern Hemisphere has $60 \%$ of occurrences for earthquakes with the highest magnitudes for the period 1986-2018.

SC22-QUAKES $M \geq 7.8$



SC23-QUAKES $M \geq 7.8$
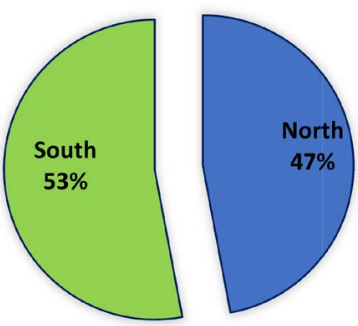

SC24- QUAKES $M \geq 7.8$

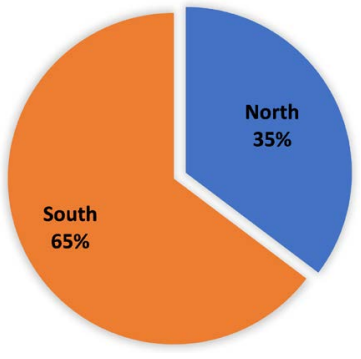

SC22- QUAKES $M \geq 7.8$



SC23- QUAKES M $\geq 7.8$



SC 24 - QUAKES $M \geq 7.8$

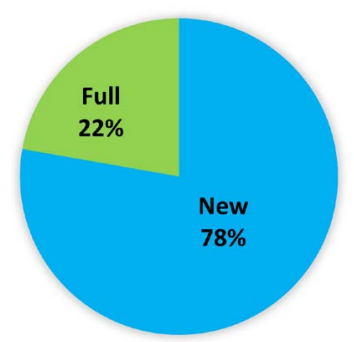

Figure 11. It shows the relationship for Tables 7-9 into cycles, SC22, SC23, and SC24. The events are occurring most at the Southern Hemisphere at the New Moon phase with magnitudes $M \geq 7.8$. 


\section{Results Discussion}

The first part of this paper calculated an oscillatory force between Moon-Earth that is created with the variation of the Perigee position twice or three times by month. Our results find an oscillatory tidal force varying during the last three Solar Cycless. Those cycles were defined within the period 1986-2019, one Solar Cycles is defined in periods of 10 - 11 years. The gravitational force Moon-Earth is an oscillation that has maximum and minima when the distance between the two bodies is at the perigee or the minima. Our next step was to associate the evolution of these oscillations and the largest earthquakes happened into the period 1986-2018.

The Moon phases are cyclical as well, and each month there is the occurrence of Full, first quarter, third quarter and New Moon. The rotational movement of the Moon around the Earth is stable, systematically along the months, and the variation for the perigee is small. Our results pointed out that gravitational force Moon-Earth has small growths during some periods and decreases if the distance between the two bodies increases. The disruption of the external parameters happens during Solar Storms, Coronal Mass Ejection or a geomagnetic storm towards the day magnetosphere, when the Solar wind speed sudden increases.

If the solar wind is strong enough or if the magnetic field inside the wind cancels the magnetic field of the Earth, some plasma can get through. Strong bursts of solar wind can squeeze the Earth's magnetosphere compressing until it bounces back like a vibrating rubber ball. Those abrupt external variations would disturb the earthquakes occurrence, as explained in [1]. The explanation for our results that the largest earthquakes happened during the New Moon at the Southern Hemisphere, is that at the New Moon the gravitational forces Sun-Moon are aligned with the Earth increasing the effects of both bodies. At the Southern Hemisphere is the location with the majority of the subduction zones easily influenced by the tidal forces from the Sun-Moon during this period.

The occurrences of earthquakes are always higher at the Southern Hemisphere, particularly in the last cycle SC 24 the proportionality was $66 \%$ of events were at the Southern. Examining the next search about the causality of New or Full Moon occurrence for larger earthquakes $M \geq 7.5$ it is found that for all cycles, the incidence of events on the New moon is above 50\% in relation to Full Moon.

A last remark is about the influence of the Sun on Earth that remains into the electromagnetic force interactions between the two bodies rather than gravitational ones.

\section{Conclusion}

Our conclusions point out that Sun-Moon-Earth may interact with each other influencing the largest earthquakes. However, those larger events mostly showed 
to be dependent in the area searched. It is contingent on the tectonics, fabric, and zones involved in the study. The locations more susceptible to the Moon-Earth relations are in the Southern Hemisphere. The presence of the subduction is important, and most are located in the Northern or Southern Pacific. However, there is a very deep subduction location at the Southern Pacific, as in Fiji with $700 \mathrm{~km}$ depth. Finally, the influence of external variables, such as Sun-Earth, Moon-Earth or Sun-Moon-Earth is subtle and is dependent from the location where the event happened. A next study could be developed to understand the importance of Moon gravitational forces for earthquakes with smaller magnitudes as $M \geq 5$ or for shallow earthquakes.

\section{Conflicts of Interest}

The authors declare no conflicts of interest regarding the publication of this paper.

\section{References}

[1] Tavares, M. and Azevedo, A. (2011) Influences of Solar Cycles on Earthquakes. Natural Science, 3, 436-443.

[2] Hagen, M. and Azevedo, A. (2016) Gravitational Moon-Earth Forces Triggering Earthquakes in Subduction Zones. Journal of Geography, Environment and Earth Science International, 8, 1-14. https://doi.org/10.9734/JGEESI/2016/29227

[3] Hagen, M. and Azevedo, A. (2017) Sun-Moon-Earth Interactions, External Factors for Earthquakes. Natural Science, 9, 162-180.

[4] NGDC/NOAA. http://www.ngdc.noaa.gov/hazard

[5] https://spaceplace.nasa.gov/solar-cycles/en

[6] Perigee/Apogee. https://www.fourmilab.ch/earthview/pacalc.html

[7] http://astropixels.com/ephemeris/phasescat/phasescat.html

[8] http://www.usgs.gov/earthquakes

[9] http://www.iris.edu/

[10] https://www.emsc-csem.org/Earthquake/?filter=yes

[11] Wayne, L., Hamilton, W.L., Lammlein, D., Dorman, J. and Latham, G. (4040) Tidal Triggering of Moonquakes. Science, 176, 1258-1259. https://doi.org/10.1126/science.176.4040.1258

[12] Marilia, H. and Azevedo, A. (2017) Possible Connections between X-Solar Flares and Worldwide Variation in Seismicity Enhancement. Natural Science, 9, 457-476. https://doi.org/10.4236/ns.2017.912042

[13] Solar Physics and Terrestrial Effects. Chapter 4, 29-38. http://www.swpc.noaa.gov/sites/default/files/images/u33/Chapter 4.pdf

[14] Block, L.P. and Falthammar, C.-G. (1968) Effect of Field-Aligned Currents on the Structure of Ionosphere (Magnetic Field-Aligned Electric-Currents Effects on Ionospheric Structure, Noting Electron Concentration Variations and Plasma Diffusion). Journal of Geophysical Research, 73, 4807-4812.

https://doi.org/10.1029/JA073i015p04807

[15] Armstrong, J.C. and Zmuda, A.J. (1970) Triaxial Magnetic Measurements of Field-Aligned Currents at 800 Kilometers in the Auroral Region: Initial Results. 
Journal of Geophysical Research, 78, 6802-6807.

https://doi.org/10.1029/JA078i028p06802

[16] Potemra, T.A. (1988) Birkeland Currents in the Earth's Magnetosphere. Astrophysical and Space Science, 144, 155-169. https://doi.org/10.1007/978-94-009-3021-6 12

[17] Kvale, E.P (2006) The Origin of Neap-Spring Tidal Cycles. Marine Geology, 235, 5-18. https://doi.org/10.1016/j.margeo.2006.10.001

[18] Ross, D.A. (1995) Introduction to Oceanography. Harper Collins, New York, 236-242.

[19] Thurman, H.V. (1994) Introductory Oceanography. Seventh Edition, HarperCollins, New York, 252-276. 